удК 657

\title{
ВЕДЕННЯ БУХГАЛТЕРСЬКОГО ОБЛІКУ В УМОВАХ ВПРОВАДЖЕННЯ СУЧАСНИХ ІНФОРМАЦІЙНИХ ТЕХНОЛОГІЙ
}

\author{
IMPLEMENTATION OF ACCOUNTING \\ IN THE CONDITIONS OF IMPLEMENTATION \\ OF MODERN INFORMATION TECHNOLOGIES
}

\author{
Бабінська Соломія Ярославівна \\ кандидат економічних наук, асистент, \\ Національний університет «Львівська політехніка» \\ ORCID: https://orcid.org/0000-0001-6169-9407
}

\author{
Babinska Solomiia \\ Lviv Polytechnic National University
}

\begin{abstract}
У статті розглянуто сутність технології блокчейн, її значення у процесі ведення бухгалтерського обліку на підприємстві. Визначено основні переваги та недоліки, які можуть виникнути при застосуванні технології блокчейн у процесі ведення бухгалтерського обліку на суб'єктах господарської діяльності. Запропоновано послідовність етапів впровадження блокчейну у процес ведення бухгалтерського обліку та визначено завдання, які виникають на кожному з них. Передбачено такі етапи: розробляння, впровадження та використання. Перший етап (розробляння) полягає у формулюванні мети та завдань щодо впровадження даної технології. Після чого слід перейти до наступного етапу (впровадження), де важливим моментом є коригування внутрішніх нормативів ведення бухгалтерського обліку та організаційної структури на підприємстві. І останнім етапом (використання) є виконання усіх робіт від захисту інформації до розподілу доступу і відповідальності за здійснювані процеси.
\end{abstract}

Ключові слова: інфрормація, бухгалтерська інфрормація, інфрормаційне забезпечення, інфрормаційні технології, технологія блокчейн.

В статье рассмотрена сущность технологии блокчейн, ее значение в процессе ведения бухгалтерского учета. Определены основные преимущества и недостатки, которые могут возникнуть при применении технологии блокчейн в процессе ведения бухгалтерского учета на субъектах хозяйственной деятельности. Предложена последовательность этапов внедрения блокчейну в процесс ведения бухгалтерского учета и определены задачи, которые возникают на каждом из них. Предусмотрены следующие этапы: разработка, внедрение и использование. Первый этап (разработки) заключается в фрормулировке цели и задач по внедрению данной технологии. После чего следует перейти к следующему этапу (внедрение), где важным моментом является корректировка внутренних нормативов ведения бухгалтерского учета и организационной структуры на предприятии. И последним этапом (использования) является выполнение всех работ от защиты инорормации к распределению доступа и ответственности за совершаемые процессы.

Ключевые слова: информация, бухгалтерская информация, информационное обеспечение, информационные технологии, технология блокчейн.

In today's world hard imagine process of maintenance accounting at the enterprise without use of automation tools. For this purpose in the article considers the essence of blockchain technology, it's importance in the process of accounting at the enterprise. Definitely the main advantages and disadvantages that may arise when using blockchain technology in the process of accounting in business entities. Suggested sequence stages of implementation of the blockchain in the accounting process and identified the tasks that must be performed on each of them. Namely provided such stages as: development, implementation and use. The first stage (development) is formulation of goals and objectives for the implementation of this technology. Whereupon should move on to the next stage (implementation), the essence of which is to improve document management, internal adjustment standards accounting and adjustment of organizational structure. And the last stage (use) is to perform the following works: information protection; carrying out identification and authentication; granting right access to the responsibilities required; distribution 
of access and responsibility for ongoing processes. In general, a blockchain should be understood as a database, which displays all operations performed in the system, which is created in the form of blocks of information, each of which records a certain number of operations and each subsequent block contains part of the information of the previous block. The introduction of blockchain technology will make it possible to synchronize accounting records, which in turn will allow for automated audits in the future. Therefore, accounting with the use of modern information technology has a number of advantages, which primarily consist in the efficiency of formation, signing, transmission and use of information, reports, documents, the ability to remotely access the necessary information and more. The key points in the implementation of such technology are: the use of electronic document management, setting up remote work, the use of cloud technologies, which in turn requires training of accounting staff.

Keywords: information, accounting information, information support, information technologies, blockchain technology.

Постановка проблеми. В той час коли на підприємствах Європи та США ручний спосіб опрацювання облікової інорормації майже не використовують, в Україні ж на деяких підприємствах ведення обліку здійснюється або без використання жодних інформаційних технологій або ж з використанням програм, які не $\epsilon$ спеціалізованим програмним забезпеченням у сорері бухгалтерського обліку. Тому доцільним є огляд сучасних інформаційних технологій для автоматизації процесу ведення бухгалтерського обліку, фрормування звітності та визначення перспектив їх впровадження для використання на вітчизняних підприємствах.

Розвиток IT-технологій $\epsilon$ передумовою зміни процесу управлінських та облікових процедур, збору, опрацювання та зберігання інсрормації тощо. Застосування таких інноваційних IT-технологій вже сьогодні надає можливість в найкоротші терміни збирати та опрацьовувати великі масиви інформації. Зокрема, таким вимогам і відповідає технологія блокчейн. Саме тому важливим є дослідження питань щодо удосконалення ведення обліку на основі технології блокчейн.

Аналіз останніх досліджень і публікацій. Публікації, які стосуються блокчейн тенології почали з'являтись лише після 2014 року. Дослідженням таких питань займались такі науковці: Л.А. Ватсон, Р. Ваттенгофер, Р.О. Гартінгер, Дж. Даі, Дж.Г. Койн, К. Лахані, Р.А. Немер, О.В. Мельниченко, К.І. Редченко, Н.Л. Шишкова, Н.Л. Ющенко та ін. Проте, не зважаючи на значну кількість досліджень система обліку на вітчизняних підприємствах ще не готова до сучасних технологічних тенденцій, зокрема i до запровадження технології блокчейн. Причиною такого стану $є$ недостатність наукових положень та розробок пов'язаних з використанням таких технологій в практиці ведення бухгалтерського обліку.

Мета статті полягає у визначенні основних переваг та недоліків, які можуть виникнути при застосуванні технології блокчейн у процесі ведення бухгалтерського обліку та фрор- муванні етапів впровадження блокчейну у процес ведення бухгалтерського обліку.

Виклад основного матеріалу. Чим більший розмір суб'єкта господарювання, тим більші обсяги інформації доводиться опрацьовувати та зберігати. Тому ведення обліку в ручну призводить до великих ризиків виникнення помилок, збільшення часу на опрацювання інформації, труднощами у процесі зберігання. Глобальна діджиталізація не оминула і сореру ведення бухгалтерського обліку, контролю та управління загалом.

У сучасному світі важко уявити процес ведення бухгалтерського обліку на підприємстві без використання засобів автоматизації. Проте, в Україні однією і з проблем залишається не достатньо сорормована методологія використання автоматизованої фрорми ведення бухгалтерського обліку. Також і свій внесок у цю проблему додав перехід на Міжнародні стандарти фрінансової звітності, що також зумовлює потребу удосконалення використовуваних програмних продуктів.

Такі країни, як США, Китай, Сінгапур, Великобританія, Нова Зеландія, Естонія, Японія, Ізраїль - є лідерами з розвитку діджиталізації [1]. Ці країни займаються розробкою та фрінансуванням програм щодо дослідження і застосування технології блокчейн (англ. blockchain, block - блок, chain - ланцюжок). Ця технологія полягає у захисті суб'єктів, які здійснюють обмін інфрормацією від ризику порушення конфріденційності інфрормації та забезпеченні її достовірності.

У більшості країн світу частка цифррової економіки збільшується, що надає величезні переваги для ведення бізнесу та розвитку країни загалом. В Україні ж одним із перших кроків щодо розбудови цисррової економіки стало Розпорядження Кабінету Міністрів України № 67 Р від 17 січня 2018 року «Про концепцію розвитку цифрової економіки та суспільства України на 2018-2020 роки».

Проте, станом на 2020 рік, в Україні ще не всі підприємства використовують комп'ютери 
у своїй діяльності (97,3\%), а доступ до Інтернету мають 99,2\% підприємств [3]. В той час, коли ведення бухгалтерського обліку можна автоматизувати приблизно на 90\%.

Бухгалтер у своїй діяльності може використовувати безліч програмних продуктів, для ведення обліку, фрормування звітності, організації документообігу тощо. Адже у сучасних умовах він $€$ основним постачальником облікової інфрормації, яка використовується для прийняття управлінських рішень.

Багато фахівців стверджують, що майбутнє бухгалтерського обліку має передбачати використання і впровадження блокчейну у практику ведення бухгалтерського обліку на підприємстві. Блокчейн - це база даних усіх операцій, які проводяться в системі, що створюється у вигляді блоків інфрормації, у кожному з яких записана певна кількість операцій і при цьому кожний наступний блок містить у собі частину інорормації попереднього блоку [5, с. 141-143].

Необхідність блокчейну у практиці ведення бухгалтерського обліку полягає у тому, що система на постійній основі перевіряє інфрормацію в блоках. У разі здійснення будь-якої операції система повідомляє про це, одночасно при цьому здійснює запис в новому блоці. Така система відстежує всі фрінансові операції в реальному часі та повідомляє про усі зміни не допускаючи при цьому помилок чи шахрайства.

На відміну від інших баз даних змінити або видалити записи не можливо, $є$ можливість додати нові лише. Така база є децентралізованою, тобто не належить жодному учаснику, для неї властивою $€$ анонімність (усі фрункції розподіляються між учасниками). Саме тому, технологію блокчейну багато науковців вважають ідеальною для ведення бухгалтерського обліку, адже з її допомогою можна відстежити усі господарські операції, бути в курсі усіх змін, не допускати помилок та перекручень чи інших маніпуляцій з інфрормацією тощо.

Не даремно технологію блокчейн називають ланцюжком, оскільки інфрормацію зберігають безліч незалежних користувачів і навіть якщо один чи кілька комп'ютерів у системі дасть збій у роботі, інфрормація не пропаде. Реєстр операцій не зберігається на сервері лише одної організації, адже його копії оновлюються одразу на безлічі комп'ютерів, які об'єднані через Інтернет. Тобто, коли відбувається декілька операцій, то запаси по них включаються в один блок, де відображено інфрормацію хто, кому, коли, в якому обсязі здійснив транзакцію.
Звіт, опублікований KPMG у 2018 р., показує, що серед цифрових технологій, які зараз застосовуються у фрінансах й бухгалтерському обліку, технологія блокчейн знаходиться на початковому етапі: лише $1 \%$ підприємств використовують ії̈ на зрілому рівні, в той час як 74 \% підприємств говорять про повну незрілість застосування блокчейну [8, с. 9].

У таблиці 1 визначено основні переваги та недоліки, які можуть виникнути при застосуванні технології блокчейн у процесі ведення бухгалтерського обліку.

Проте, нормативно операції, які ґрунтуються на технології блокчейн, сьогодні в Україні ніяк не регламентуються. Саме це може бути однією із перешкод для початку впровадження та використання у практиці ведення бухгалтерського обліку блокчейн-платформ. 3 плином часу паперові документи підуть у минуле, адже вже зараз електронний документообіг полегшив роботу фрахівців багатьох ссрер, в тому числі і бухгалтерів.

Запропоновано застосовувати такі етапи впровадження технології блокчейн у процес ведення бухгалтерського обліку (рис. 1).

На першому етапі (розробляння) необхідно сорормулювати мету та завдання щодо впровадження даної технології. Після чого слід перейти до наступного етапу (впровадження), де важливим моментом $€$ коригування внутрішніх нормативів ведення бухгалтерського обліку та організаційної структури на підприємстві. І останнім етапом (використання) є виконання усіх робіт від захисту інорормації до розподілу доступу і відповідальності за здійснювані процеси. Проте, досить обмеженими для застосування блокчейну будуть оцінка та калькулювання. Загалом, питання, які вимагають власного судження бухгалтера або аудитора, i в майбутньому будуть вимагати пильної уваги.

Висновки. Для підвищення достовірності, прозорості та якості інфрормації, яка $€$ основою для прийняття ефективних управлінських рішень слід використовувати сучасні інсрормаційні технології, до яких, зокрема належить, технологія блокчейн. Запровадження такої технології дасть змогу синхронізувати бухгалтерські записи, що в свою чергу у майбутньому дасть змогу проводити і автоматизований аудит. Тому, бухгалтерський облік 3 використанням сучасних інфрормаційних технологій має низку переваг, які перш за все полягають у оперативності фрормування, підписання, передачі та використання інорормації, звітів, документів, можливості віддаленого доступу до необхідної інфрормації тощо. Клю- 


\section{Переваги та недоліки застосування технології блокчейн у процесі ведення бухгалтерського обліку}

\begin{tabular}{|c|c|}
\hline Переваги & Недоліки \\
\hline Зниження ризику втрати інформації. & $\begin{array}{l}\text { Високий рівень ризику, пов'язаний } \\
\text { з оцифруванням документів. }\end{array}$ \\
\hline $\begin{array}{l}\text { Зменшення кількості бухгалтерських помилок, } \\
\text { що одночасно підвищує достовірність } \\
\text { бухгалтерської інфрормації. }\end{array}$ & $\begin{array}{l}\text { Відсутність законодавчо-нормативної бази } \\
\text { чи стандартів щодо регулювання операцій } \\
\text { з використанням технології блокчейн. } \\
\end{array}$ \\
\hline $\begin{array}{l}\text { Прозорість ведення бухгалтерського обліку. } \\
\text { Боротьба з шахрайством, що дасть змогу забез- } \\
\text { печити прозорість ведення обліку та реальність. } \\
\text { Ухилення від сплати податків стане просто не } \\
\text { можливим, так як всі операції, угоди будуть оцифр- } \\
\text { ровані та зберігатимуться на певній платформі, } \\
\text { яка сама розрахує податки і платежі тощо. }\end{array}$ & $\begin{array}{l}\text { Висока вартість програмного } \\
\text { забезпечення та значні витрати } \\
\text { на забезпечення працівників відповідною } \\
\text { технікою. }\end{array}$ \\
\hline $\begin{array}{l}\text { Зниження витрат на організацію відділу } \\
\text { бухгалтерії. }\end{array}$ & $\begin{array}{l}\text { Неможливість визначення ефективності } \\
\text { від використання технології блокчейну. }\end{array}$ \\
\hline $\begin{array}{l}\text { Підвищення рівня захисту та збереження } \\
\text { інфрормації. Оскільки, база даних не зберігається } \\
\text { в одному місці, а розподілена серед декількох } \\
\text { тисяч комп'ютерів у всьому світі. }\end{array}$ & Нестача кваліфрікованих працівників. \\
\hline \multirow{2}{*}{$\begin{array}{l}\text { Оновлення в режимі реального часу. Інфрормація } \\
\text { про здійснені господарські операції одразу } \\
\text { з'являється в усіх сторін договору. }\end{array}$} & \begin{tabular}{|l} 
Метод подвійного запису доповниться \\
третім, який призначений для \\
підтвердження операції у блокчейні.
\end{tabular} \\
\hline & $\begin{array}{l}\text { Безповоротність внесення операцій, } \\
\text { коли при помилковому введені даних, } \\
\text { виправити їх практично неможливо. }\end{array}$ \\
\hline
\end{tabular}

Джерело: складено автором

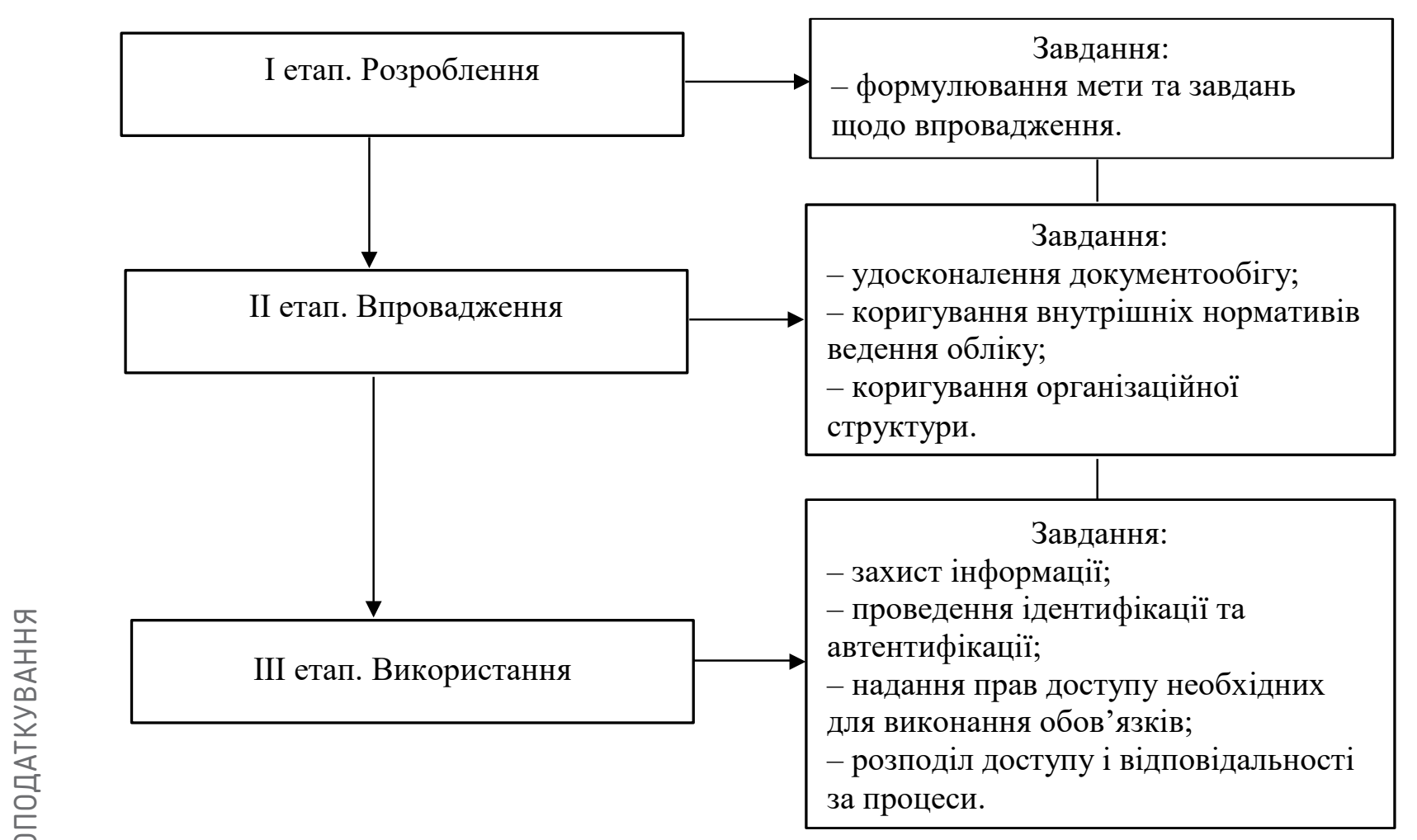

Рис. 1. Послідовність впровадження блокчейн технології у процес ведення бухгалтерського обліку 
човими моментами при впровадженні таких технологій $є$ : застосування електронного документообігу, налагодження дистанційної роботи, використання хмарних технологій, що у свою чергу вимагає підвищення кваліфікації бухгалтерських працівників.

\section{СПИСОК ВИКОРИСТАНИХ ДЖЕРЕЛ:}

1. Діджиталізація - це лише початок. URL: https://day.kyiv.ua/uk/article/ekonomika/didzhytalizaciya-ce-lyshepochatok (дата звернення: 16.04.2021).

2. Криворучко Г. В. Технологія блокчейн та перспективи їі застосування в процесі бюджетування, орієнтованого на результат. Вісник економічної науки України. 2018. № 2. С. 108-113.

3. Ооріційний сайт Державної служби статистики України. URL: http://www.ukrstat.gov.ua (дата звернення: 15.04.2021).

4. Попівняк Ю. М. Технологія блокчейн у бухгалтерському обліку й аудиті: сучасний стан, можливості та перспективи застосування. Економіка, управління та адміністрування. 2019. № 3(89). С. 137-144.

5. Ситник І. П., Фоміна В. С. Вплив фінтеху на розвиток сучасних платіжних систем України. Наукововиробничий журнал «Бізнес-навігатор». 2019. Випуск 2(15). С. 139-143.

6. Спільник І., Палюх М. Бухгалтерський облік в умовах цифрової економіки. Міжнародний науковий журнал. Інститут бухгалтерського обліку, контроль та аналіз в умовах глобалізації. 2019. № 1-2. С. 83-96.

7. Шишкова Н. Л. Перспективи впровадження блокчейну в бухгалтерському обліку. Облік і фрінанси. 2018. № 2. C. 61-68.

8. Employing advanced technologies to transform finance // KPMG Global Insights Pulse Survey Report. Cambridge : KPMG International Cooperative, 2018. 17 p.

\section{REFERENCES:}

1. Didzhitalizatsiya - tse lishe pochatok [Digitalization is just the beginning]. Available at: https://day.kyiv.ua/uk/ article/ekonomika/didzhytalizaciya-ce-lyshe-pochatok (accessed 16 April 2021).

2. Krivoruchko G. V. (2018) Tehnologiya blokcheyn ta perspektivi ii zastosuvannya v protsesi byudzhetuvannya, orientovanogo na rezultat [Technology blockchain and prospects for it's application in the budgeting process, result-oriented]. Visnik ekonomichnoyi nauki Ukrayini, 2, 108-113.

3. Ofitsiyniy sayt Derzhavnoyi sluzhbi statistiki Ukrayini [Official site of the State Statistics Service of Ukraine]. Available at: http://www.ukrstat.gov.ua (accessed 15 April 2021).

4. Popivnyak Yu. M. (2019) Tehnologiya blokcheyn u buhgalterskomu obliku y auditi: suchasniy stan, mozhlivosti ta perspektivi zastosuvannya [Blockchain technology in accounting and auditing: current status, opportunities and prospects for application]. Ekonomika, upravlinnya ta administruvannya, 3(89), 137-144.

5. Sitnik I. P., Fomina V. S. (2019) Vpliv fintehu na rozvitok suchasnih platizhnih sistem Ukrayini [Influence fintech for the development of modern payment systems in Ukraine]. Naukovo-virobnichiy zhurnal «Biznes-navigator», 2(15), 139-143.

6. Spilnik I., Palyuh M. (2019). Buhgalterskiy oblik v umovah tsifrovoyi ekonomiki [Accounting in the digital economy]. Mizhnarodniy naukoviy zhurnal. Institut buhgalterskogo obliku, kontrol ta analiz v umovah globalizatsiyi, 1-2, 83-96.

7. Shishkova N. L. (2018) Perspektivi vprovadzhennya blokcheynu v buhgalterskomu obliku [Prospects for the introduction of blockchain in accounting]. Oblik i finansi, 2, 61-68.

8. Employing advanced technologies to transform finance (2018). KPMG Global Insights Pulse Survey Report. Cambridge. KPMG International Cooperative, 17. 